\title{
IMPLEMENTASI UNDANG-UNDANG NOMOR 21 TAHUN 1992 TENTANG PELAYARAN DIKAITKAN DENGAN LEGALITAS PENGELOLAAN KAPAL CEPAT KARTINI 1 JALUR JEPARA-KARIMUNJAWA-SEMARANG
}

\author{
LUSI ARJUNI, S.S
}

\begin{abstract}
ABSTRAK
Kapal Cepat Kartini 1 sebagai alat transportation dari Jepara Karimunjawa atau Semarang - Karimunjawa, operasionalnya dikelola oleh Dinas Perhubungan, Komunikasi dan Informatika Provinsi Jawa Tengah dan Dinas Perhubungan Kabupaten Jepara, yang merupakan instansi pemerintah dan seharusnya berfungsi sebagai regulator.

Dalam tesis ini permasalahan yang dibahas adalah bagaimana undang-undang pelayaran mengatur tentang usaha angkutan laut, kesesuaian pelaksanaan pengelolaan Kapal Cepat Kartini 1 terhadap undang-undang pelayaran dan faktor-faktor kendala yang muncul dalam pengelolaan Kartini 1.

Dengan menggunakan analisis kualitatif, penelitian ini bertitik tolak dari metode pendekatan yuridis-sosiologis atau normatif-empiris dengan mempelajari dan meneliti peraturan tentang pelayaran yang mengatur tentang usaha angkutan laut. Kemudian, peraturan tersebut dikaitkan dengan pelaksanaan pengelolaan Kapal Cepat Kartini 1.

Hasil penelitian menunjukkan bahwa (1) Pengelolaan Kapal Cepat Kartini 1 seharusnya dikelola oleh Badan Hukum Indonesia atau warga Negara Indonesia yang mendapat izin dari pemerintah dan khusus bergerak dibidang pelayaran. (2) Pengelolaan Kapal Cepat Kartini 1 belum sesuai dengan undang-undang pelayaran yang ada. (3) Ada beberapa kendala yang muncul dalam pengelolaan Kapal Cepat Kartini 1. Kendalakendala tersebut muncul karena faktor kelembagaan, faktor keuangan, faktor sarana/prasarana wisata dan faktor keuntungan.

Akhirnya, penulis memberikan saran bahwa Pengelolaan Kapal Cepat Kartini 1 harus diserahterimakan kepada pihak ketiga atau Badan Hukum Indonesia atau warga Negara Indonesia yang mempunyai usaha khusus di bidang angkutan laut tau pelayaran.

Kata kunci : Angkutan Laut, Pelayaran, Pengelolaan.
\end{abstract}




\section{A. PENDAHULUAN}

\section{LATAR BELAKANG}

Indonesia dikenal sebagai Negara maritim yang mempunyai luas laut lebih besar dibandingkan dengan luas daratan. Oleh karena itu, sarana transportasi laut perlu dikembangkan dan ditingkatkan lebih baik, karena transportasi laut adalah sebagai sarana komunikasi dan penghubung antar pulau dalam mewujudkan persatuan, kesatuan, pertahanan, dan keamanan di berbagai sektor, baik sektor sosial, politik, budaya maupun ekonomi. ${ }^{1}$ Sehubungan dengan hal itu, maka pemerintah mengeluarkan peraturan yaitu PP No. 17 Tahun 1988 tentang Penyelenggaraan dan Pengusahaan Angkutan Laut.

Namun demikian, masih banyak daerah-daerah terpencil / pedalaman yang belum disentuh oleh para pihak yang berwenang sehingga belum dikembangkan secara maksimal. Oleh karena itu, pihak yang berwenang hendaknya membuka akses ke daerahdaerah tersebut dengan memberikan sarana transportasi yang mudah, murah dan lancar sehingga dapat meningkatkan roda perekonomian masyarakat setempat. Di Provinsi Jawa Tengah, salah satu daerah yang masih belum dikembangkan secara maksimal adalah Kepulauan Karimunjawa yang masuk wilayah Kabupaten Jepara.

Kerjasama Pemerintah Provinsi Jawa Tengah dan Pemerintah Kabupaten Jepara meliputi berbagai sektor, yaitu : ${ }^{2}$

a. Perhubungan dan Telekomunikasi;

b. Pariwisata;

c. Industri, Perdagangan, Promosi dan Investasi;

d. Perikanan dan Kelautan;

e. Kehutanan dan Perkebunan;

f. Pertambangan dan Energi;

Djoko Triyanto, Bekerja di Kapal, Mandar Maju, Bandung, 2005, hal. 1.

Keputusan Bersama Gubernur Jawa Tengah dan Bupati Jepara Nomor 55 Tahun 2004/01 Tahun 2004 tentang Kerjasama Pemerintah Provinsi Jawa Tengah dengan Pemerintah Kabupaten Jepara, BAB III PsI 3, hal 3 


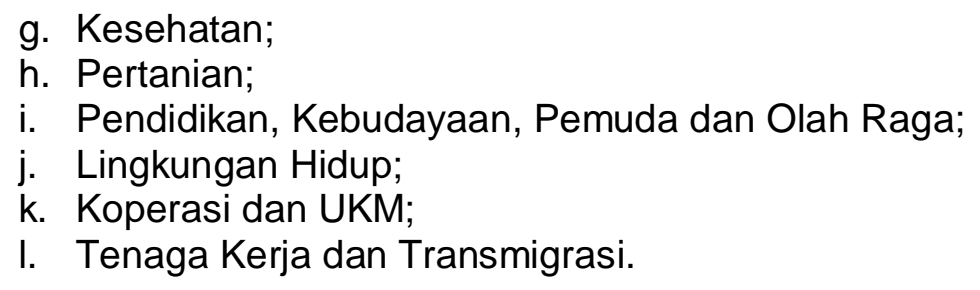

Untuk mengembangkan Kepulauan Karimunjawa yang perlu dipersiapkan terlebih dahulu adalah sektor transportasi. Selama ini transportasi yang ada adalah sebuah kapal perintis yaitu kapal penumpang dan barang, Kapal MURIA yang melayani trayek Jepara - Karimunjawa ditempuh selama 6-7 jam. Minimnya sektor transportasi sebagai akses menuju ke Karimunjawa inilah yang mengakibatkan Kepulauan itu belum berkembang dengan maksimal.

Selanjutnya, pemerintah dalam hal ini Gubernur Jawa Tengah dan Bupati Jepara, mengadakan Kesepakatan Bersama dengan PT PAL INDONESIA dalam kegiatan Pengadaan Kapal Penumpang Cepat Untuk Lintas Jepara - Karimunjawa. Tujuan Kesepakatan Bersama ini adalah untuk mengikat dan mewujudkan keinginan kedua belah pihak untuk pengadaan Kapal Penumpang Cepat untuk Lintas Jepara - Karimujawa dalam rangka meningkatkan pelayanan transportasi dan pertumbuhan kepariwisataan di Provinsi Jawa Tengah, khususnya di Kabupaten Jepara. $^{3}$

Pemerintah Provinsi Jawa Tengah dan Pemerintah Kabupaten Jepara merealisasikan kapal penumpang cepat buatan PT PAL INDONESIA pada bulan Maret 2004, yang diberi nama KARTINI 1. Pengadaan Kapal Kartini 1 semula ditujukan untuk akses transportasi laut Jepara-Karimunjawa, tetapi dengan

3 Kesepakatan Bersama Gubernur Jawa Tengah dan Bupati Jepara dengan Direktur Utama PT PAL INDONESIA No. 4 Tahun 2003 / No. 552.2/0452/2003 / No. 05/AAOO/II/2003 tentang Pengadaan Kapal Penumpang Cepat untuk Lintas Jepara - Karimunjawa, BAB I Psl 1, hal. 2 
pertimbangan permintaan banyak dan untuk meningkatkan potensi ekonomi Karimunjawa di masa depan operasional kapal cepat dikembangkan ke jalur Semarang - Karimunjawa dan Jepara Semarang. ${ }^{4}$

Setelah Kapal Penumpang Cepat Kartini 1 direalisasikan, untuk pengelolaannya diserahkan kepada Dinas Perhubungan dan Telekomunikasi Provinsi Jawa Tengah dan Dinas Perhubungan Jepara, karena instansi ini yang mempunyai wewenang dalam bidang transportasi. Menurut rencana, pada awalnya Kapal Cepat Kartini 1 akan dikelola oleh badan pengelola yang unsurnya berasal dari Dinas Perhubungan dan Telekomunikasi Provinsi Jawa Tengah dan Dinas Perhubungan Jepara. Namun demikian sampai saat ini rencana tersebut belum terealisasikan, sehingga pengelolaannya masih dibawah Dinas Perhubungan dan Telekomunikasi Provinsi Jawa Tengah dan Dinas Perhubungan Jepara. Hal ini merupakan permasalahan yang mendesak untuk dipecahkan karena tuntutan profesionalitas dan pemisahan yang jelas antara pemerintah sebagai regulator dan unit bisnis sebagai pelaku usaha. ${ }^{5}$

Mengacu pada ketentuan perundang-undangan yang berlaku yaitu Undang-Undang No. 21 Tahun 1992, PP No. 82 Tahun 1999 dan Kepmenhub No. 33 Tahun 2001. Dalam UU No. 21 Tahun 1992 tentang Pelayaran dengan jelas menegaskan bahwa penyelenggaraan angkutan di perairan dilakukan oleh badan hukum Indonesia atau warga Negara Indonesia, atas izin

\footnotetext{
Dinas Perhubungan dan Telekomunikasi Provinsi Jawa Tengah, Studi Optimalisasi Pengoperasian KPC. Kartini 1, 2007, hal 1

5 Berdasarkan Peraturan Daerah Provinsi Jawa Tengah No. 6 Tahun 2008 tentang Organisasi dan Tata Kerja Dinas Daerah Provinsi Jawa Tengah, Dinas Perhubungan dan Telekomunikasi Provinsi Jawa Tengah berubah nama menjadi Dinas Perhubungan, Komunikasi dan Informatika Provinsi Jawa Tengah yang mempunyai tugas pokok melaksanakan urusan pemerintah daerah bidang perhubungan, komunikasi dan informatika berdasarkan asas otonomi daerah dan tugas pembantuan
} 
pemerintah. Peraturan Pemerintah No. 82 Tahun 1999 tentang Angkutan di Perairan juga mengatur dan menegaskan bahwa usaha angkutan diselenggarakan oleh perusahaan angkutan laut yang berbadan hukum Indonesia berbentuk Perseroan Terbatas, Badan Usaha Milik Negara, Badan Usaha Milik Daerah maupun Koperasi yang didirikan khusus untuk usaha itu. Demikian juga Kepmenhub No. 33 Tahun 2001 tentang Penyelenggaraan dan Pengusahaan Angkutan Laut pasal 18 menyatakan bahwa usaha angkutan laut dilakukan oleh perusahaan angkutan laut yang berbadan hukum Indonesia berbentuk Perseroan Terbatas, BUMN, BUMD atau Koperasi yang didirikan khusus untuk usaha itu.

Sehubungan dengan hal tersebut di atas, maka pihak Dinas Perhubungan dan Telekomunikasi Provinsi Jawa Tengah menunjuk pihak ketiga sebagai agen yaitu sebuah perusahaan yang memenuhi persyaratan sebagai badan hukum Indonesia yang bergerak khusus di bidang usaha pelayaran yaitu PT. Pualam Emas Sejahtera. Oleh karena itu, segala urusan administrasi Kapal Cepat Kartini 1 dilakukan oleh PT. Pualam Emas Sejahtera.

Berdasarkan latar belakang tersebut di atas, maka penulis bermaksud melakukan kajian lebih jauh terhadap pengelolaan Kapal Cepat Kartini 1 dan melakukan penelitian dengan judul : "Implementasi Undang-Undang Nomor 21 Tahun 1992 tentang Pelayaran dikaitkan dengan Legalitas Pengelolaan Kapal Cepat Kartini 1 Jalur Jepara-Karimunjawa-Semarang"

\section{PERMASALAHAN}

Bertitik tolak pada uraian latar belakang di atas, maka penulis merumuskan permasalahannya sebagai berikut :

a. Bagaimanakah Undang-Undang Pelayaran mengatur masalah pengelolaan Kapal Cepat? 
b. Apakah pengelolaan Kapal Cepat Kartini 1 saat ini sudah sesuai dengan kebijakan pemerintah yang tertuang dalam UndangUndang Pelayaran?

c. Mengapa muncul kendala-kendala dalam pengelolaan Kapal Cepat Kartini 1 khususnya mengenai legitimasinya ?

\section{TUJUAN PENELITIAN}

Tujuan penelitian ini yaitu :

a. Untuk mengetahui dan menganalisa Undang-Undang Pelayaran yang mengatur tentang pengelolaan kapal

b. Untuk mengetahui dan menganalisa pengelolaan Kapal Cepat Kartini 1 sudah sesuai atau belum dengan Undang-Undang Pelayaran.

c. Untuk memahami dan mengidentifikasi faktor-faktor yang menjadi kendala dalam pengelolaan Kapal Cepat Kartini 1.

\section{TINJAUAN PUSTAKA}

Dalam negara hukum, setiap tindakan pemerintah harus berdasarkan atas hukum, karena dalam negara terdapat prinsip wetmatigheid van bestuur atau asas legalitas. Asas ini menentukan bahwa tanpa adanya dasar wewenang yang diberikan oleh suatu peraturan perundang-undangan yang berlaku, maka segala macam aparat pemerintah tidak akan memiliki wewenang yang dapat mempengaruhi atau mengubah keadaan atau posisi hukum warga masyarakatnya. Asas legalitas menurut Sjachran Basah, berarti upaya mewujudkan duet integritas secara harmonis antara paham kedaulatan hukum dan paham kedaulatan rakyat berdasarkan prinsip monodualitis selaku pilar-pilar, yang sifat hakikatnya konstitutif.

Meskipun demikian, tidak selalu tindakan pemerintahan tersedia peraturan perundang-undangan yang mengaturnya. Dalam 
kondisi seperti ini, kepada pemerintah diberikan kebebasan bertindak (discresionare power) yaitu melalui freies ermessen, yang diartikan sebagai salah satu sarana yang diberikan ruang bergerak bagi pejabat atau badan-badan administrasi negara untuk melakukan tindakan tanpa harus terikat sepenuhnya pada undangundang.

Dalam kerangka negara hukum, freies ermessen ini tidak dapat digunakan tanpa batas. Atas dasar itu, Sjachran Basah mengemukakan unsur-unsur freies ermessen dalam suatu negara hukum yaitu sebagai berikut :

1. Ditujukan untuk menjalankan tugas-tugas servis publik

2. Merupakan sikap tindak yang aktif dari administrasi negara.

3. Sikap tindak itu dimungkinkan oleh hukum.

4. Sikap tindak itu diambil atas inisiatif sendiri.

5. Sikap tindak itu dimaksudkan utuk menyelesaikan persoalanpersoalan penting yang timbul secara tiba-tiba.

6. Sikap tindak itu dapat dipertanggung jawabkan baik secara moral kepada Tuhan Yang Maha Esa maupun secara hukum.

Untuk mencapai hukum yang bermakna, diperlukan proses implementasi yang disebut penegakan hukum. Penegakan hukum merupakan suatu proses untuk mewujudkan keinginan-keinginan hukum menjadi suatu kenyataan. Satjipto Rahardjo menyebutkan bahwa keinginan-keinginan hukum dala hal ini tidak lain adalah pikiran badan-badan pembuat undang-undang yang dituangkan dalam undang-undang yang akhirnya pada proses pelaksanaannya oleh aparat penegak hukum ${ }^{6}$.

Menurut Soerjono Soekanto ada beberapa faktor yang mempengaruhi penegakan / keefektifan hukum yaitu :?

6 Satjipto Rahardjo, Masalah Penegakan Hukum, Sinar Baru, Bandung, 1986, hal.24 Soerjono Soekanto, Penegakan Hukum, Bina Cipta, Bandung, 1983, hal. 5 
1. Hukum/UU /peraturan; kalau hukum itu baik, maka ada kejelasan penafsiran, sinkronisasi baik vertikal maupun horizontal.

2. Penegak hukum (pembentuk hukum maupun penerap hukum); semua Capres, janji penegakan hukum, berantas KKN, tapi persoalannya diawali dari orangnya kemudian sistemnya.

3. Sarana atau fasilitas pendukung; Legal officer tidak profesional, semuanya menjadi tidak berfungsi maksimal. Penegak hukum yang baik, kalau peraturannya tidak memadai maka tidak akan berjalan dengan baik.

4. Masyarakat; banyak masyarakat yang tidak memiliki kesadaran hukum sehingga kadang hukum hanya berhenti sampai pengaturan saja.

5. Budaya hukum (Legal Cultur); berbagai hasil karya cipta dan rasa yang didasarkan pada karsa manusia dalam pergaulan kehidupan.

Salah satu faktor tersebut diatas adalah kesadaran hukum masyarakat, menurut teori Berl Kutschinky, kesadaran hukum adalah variabel yang berisi 4 komponen yaitu ${ }^{8}$ :

1. Komponen Legal Awareness yaitu aspek mengenai pengetahuan terhadap peraturan hukum yang dimiliki oleh masyarakat. Jadi teori hukum menyatakan bahwa ketika hukum ditegakkan maka mengikat. Menurut teori residu semua orang dianggap tahu hukum tapi kenyataannya tidak begitu, maka perlu Legal Awareness. Contoh ketika akan melakukan kontrak, tahu dulu UU-nya.

2. Legal Acquaintances : pemahaman hukum. Jadi orang memahami isi daripada peraturan hukum, mengetahui substansi dari UU.

3. Legal Attitude (sikap hukum). Artinya kalau seseorang sudah memberikan apressiasi \& memberikan sikap : apakah UU baik/ tidak, manfaatnya apa.

4. Legal Behavior (perilaku hukum), orang tidak sekedar tahu, memahami tapi juga sudah mengaplikasikan. Banyak orang tidak tahu hukum tapi perilakunya sesuai hukum begitu juga banyak orang tahu hukum tapi justru perilakunya melanggar hukum. Asumsinya hal di atas dalam keadaan normal ada proses sosialisasi hukum, penyuluhan, pendidikan hukum dan seterusnya.

8 Anonim, Sosiologi Hukum Catatan, http://unisri.ac.id/anita/wpcontent/uploads/2008/09/sosiologi-hukumbarubgt.doc, akses tanggal 2 Nopember 2008. 
Sedangkan menurut E. Howard \& R.S. Summer ada beberapa syarat agar hukum dapat berlaku secara efektif yaitu ${ }^{9}$ :

1. UU dirancang dengan baik, kaidahnya jelas, mudah dipahani \& penuh kepastian.

2. UU sebaiknya bersifat malarang (prohibitur) dan bukan mengharuskan/ membolehkan (mandatur).

3. Sanksi haruslah tepat dan sesuai tujuan.

4. Beratnya sanksi tidak boleh berlebihan (sebanding dengan pelanggarannya).

5. Mengatur terhadap perbuatan yang mudah dilihat.

6. Mengandung larangan yang berkesesuaian dengan moral.

7. Pelaksana hukum menjalankan tugasnya dengan baik, menyebarluaskan UU, penafsiran seragam dan konsisten.

Transportasi sebagai salah satu sektor pembangunan yang perlu pengaturan untuk mendapatkan legitimasi dari sisi hukum. Upaya penegakan hukum di bidang transportasi sangat diperlukan untuk meningkatkan keefektivitasannya sehingga akan tercipta pelayanan jasa transportasi yang semakin baik dan lancar. Peraturan di bidang transportasi sebagai bagian dari sistem hukum nasional, menurut teori Lon L. Fuller, harus memenuhi 8 (delapan) asas legalitas atau principles legality sebagai berikut ${ }^{10}$ :

1. Sistem hukum harus mengandung peraturan-peraturan, artinya peraturan tidak boleh mengandung sekedar keputusankeputusan yang bersifat ad hoc;

2. Peraturan-peraturan yang telah dibuat itu harus diumumkan;

3. Peraturan tidak boleh berlaku surut;

4. Peraturan-peraturan disusun dalam rumusan yang bisa dimengerti;

5. Suatu sistem tidak boleh mengandung peraturan-peraturan yang bertentangan satu sama lain;

6. Peraturan-peraturan tidak boleh mengandung tuntutan yang melebihi apa yang dapat dilakukan;

7. Peraturan tidak boleh sering diubah-ubah;

8. Harus ada kecocokan antara peraturan yang diundangkan dengan pelaksanaannya sehari-hari.

Ibid

Esmi Warassih, Pranata Hukum, Sebuah Telaah Sosiologis, PT. Suryandaru Utama, Semarang, 2005, hal. 31 
Oleh karena itu, perlu kajian mengenai sinkronisasi peraturan perundang-undangan untuk mengetahui apakah kebijakan yang dituangkan dalam peraturan di bidang transportasi, khususnya Undang-Undang Pelayaran sudah sesuai dengan kedelapan asas tersebut. Karena Indonesia sebagai negara kepulauan mempunyai wilayah laut yang luas, sehingga sangat potensial untuk didayagunakan secara maksimal sehingga akan diperoleh manfaat yang sebasar-besarnya bagi negara, termasuk sistem transportasinya. Sistem transportasi laut yang handal akan mampu menjembatani berbagai pelosok daerah di tanah air dan mampu menjaga keutuhan wilayah dan integritas nasional.

Namun demikian, secara konstitusional pemerintah adalah pemegang otoritas membentuk dan melaksanakan hukum, maka patut diwaspadai segala tindakan pemerintah yang berpotensi untuk terjadinya pelanggaran hukum oleh pemerintah.

Secara umum kelaziman pelanggaran hukum oleh pemerintah itu, menurut Felix A. Nugro, dikategorikan dalam 9 (sembilan) bentuk pelanggaran ${ }^{11}$ yaitu :

1. ketidakjujuran (dishonesty)

2. Berperilaku tidak etis (unethical behavior)

3. Mengesampingkan hukum (overidding the law)

4. Memperlakukan pegawai secara tidak patut (unfair treatment of employees)

5. Melanggar prosedur hukum (violations of procedural due process)

6. Tidak menjalin kerjasama yang baik dengan pihak legislatif (failure to respect legislative intent)

7. Pemborosan dalam penggunaan sumber daya (gress inefficiency)

8. Menutup-nutupi kesalahan yang dilakukan oleh aparatur (covering up mistakes)

9. Kegagalan untuk melakukan inisiatif dan terobosan yang positif (failure to show inisiative)

11 Winahyu Erwiningsih, Makalah Peranan hukum dalam Pertanggungjawaban Perbuatan Pemerintah (Bestuurshandeling) Suatu Kajian dalam Kebijakan Pembangunan Hukum 
Kenyataan menunjukkan bahwa hukum hanya dipergunakan sebagai alat untuk mengatur rakyat belaka dan yang dijadikan acuan bagi pemerintah dan pemegang kekuasaan lainnya. Hal ini yang disadari oleh semua pihak agar tercipta kondisi negara yang mapan dan rakyat sejahtera, maka hukum harus diperlakukan sebagai penglima dalam negara hukum.

\section{METODE PENELITIAN}

Metode pendekatan yang digunakan dalam penelitian ini adalah pendekatan yang bersifat yuridis sosiologis atau yuridis empiris, yaitu penelitian yang mengkaitkan antara aspek hukum dan aspek non hukum. Penelitian dilakukan terhadap aturan-aturan hukum di bidang pelayaran, dan dikaji untuk mengetahui seberapa jauh peraturan yang ada diimplementasikan dilapangan. Dalam hal ini hokum dipandang sebagai sarana atau alat untuk mengatur masyarkat, yang tidak lepas dari pengaruh aspek sosial, ekonomi dan aspek-aspek lainnya.

Pendekatan ini berpegang pada suatu pandangan yang menyatakan bahwa hukum sebagai norma, kaidah dan peraturan yang berlaku dalam masyarakat yang sesuai dengan prinsip-prinsip dan asas-asas hukum. ${ }^{12}$

Penelitian yuridis sosiologis adalah penelitaian hukum yang dilakukan dengan cara mengkaji dan meneliti peraturan-peraturan yang dilakukan dengan cara mengkaji dan meneliti peraturanperaturan yang berkaitan dengan angkutan pelayaran kemudian dihubungkan dengan pengelolaan KPC. Kartini 1 di lapangan apakah sudah sesuai dengan peraturan-peraturan yang ada.

2 Soetandyo Wignjosoebroto, Masalah metodologi dalam Penelitian Hukum sehubungan dengan Masalah Keragaman Pendekatan Konseptualnya, Makalah pada Pelatihan Metodologi Penelitian, Fak. Hukum UNDIP, Mei 1999, hal 30 


\section{B. HASIL PENELITIAN DAN PEMBAHASAN}

\section{PENGELOLAAN KAPAL CEPAT KARTINI 1 MENURUT UNDANG-UNDANG PELAYARAN}

Dalam Undang-Undang Nomor 21 Tahun 1992 tentang Pelayaran yang sudah diperbaharui menjadi Undang-Undang Nomor 17 Tahun 2008 tentang Pelayaran, usaha angkutan di perairan sudah jelas aturannya yaitu tertuang dalam pasal 69 dan pasal 70. Kedua Pasal tersebut menyatakan bahwa penyelenggaraan usaha angkutan di perairan dilakukan oleh badan hukum Indonesia yang bergerak khusus di bidang usaha angkutan di perairan dan usaha angkutan di perairan dapat juga diselenggarakan oleh warga negara Indonesia dengan izin pemerintah. Sedangkan dalam Undang-Undang Pelayaran yang baru (UU No. 17 Th. 2008), angkutan laut diatur dalam Pasal 27 dan 28, dimana dalam Pasal 27 dijelaskan yaitu; untuk melakukan kegiatan angkutan di perairan orang perseorangan warga negara Indonesia atau badan usaha wajib memiliki izin usaha.

Berdasarkan ketentuan-ketentuan tersebut diatas maka dapat dijelaskan bahwa usaha angkutan perairan dilakukan oleh badan hukum Indonesia atau warga negara Indonesia dengan izin pemerintah. Demikian juga halnya dengan Kapal Cepat Kartini 1 sebagai alat angkutan di perairan pengelolaannya harus berpijak pada ketentuan-ketentuan yang telah diatur dalam Undang-Undang Pelayaran, maka pengelolaan Kapal Cepat Kartini 1 harus ditangani oleh sebuah badan usaha yang berstatus badan hukum Indonesia atau warga negara Indonesia dengan izin pemerintah.

Disamping berpijak pada Undang-Undang Nomor 21 Tahun 1992 yang sudah diperbaharui Undang-Undang Nomor 17 Tahun 2008 tentang pelayaran, pengelolaan Kapal Kartini I juga berpijak pada peraturan-peraturan pendukung yang lain yaitu: 
1. Peraturan Pemerintah No. 82 Tahun 1999 tentang Angkutan di Perairan sebagai peraturan pelaksana dari UU no. 21 Tahun 1992.

2. Keputusan Menteri Perhubungan No. 33 tahun 2001 tentang Penyelengaraan dan Pengusahaan Angkutan Laut.

3. Peraturan Gubernur Jawa Tengah Nomor 523 tahun 2008 tentang Penunjukkan Kepala Dinas Perhubungan Komunikasi dan Informatika Provinsi Jawa Tengah sebagai Pengelola Kapal Penumpang Cepat Kartini 1

Merujuk pada Undang-Undang Pelayaran dan peraturanperaturan pendukung lainnya, pengelolaan Kapal Kartini 1 sudah seharusnya dikelola oleh sebuah badan hukum Indonesia, bisa berupa BUMN, BUMD, Badan Layanan Umum Daerah, Koperasi atau badan usaha swasta berbadan hukum yang bergerak khusus di bidang pelayaran. Namun dalam praktek di lapangan, pengelolaan Kapal Kartini 1 dilakukan oleh Dinas Perhubungan, Komunikasi dan Informatika Provinsi Jawa Tengah dan Dinas Perhubungan Kabupaten Jepara yang merupakan instansi pemerintah. Seperti yang diungkapkan oleh Kasie Angkutan Laut Dinhubkominfo Provinsi Jawa Tengah, bahwa pengelolaan apal cepat Kartini 1 seharusnya dikelola oleh badan usaha yang berstatus atau memiliki badan hukum tidak seperti dalam pengelolaannya saat ini.

Menurut Soerjono Soekanto ${ }^{13}$ salah faktor yang mempengaruhi penegakan / kefektifan hukum adalah Hukum/UU/peraturan. Artinya kalau hukum itu baik, maka ada kejelasan penafsiran, sinkronisasi baik vertikal maupun horisontal. Bertitik tolak dari uraian di atas, Undang-Undang/peraturan tentang pelayaran sudah mengatur dengan jelas mengenai penyelenggaraan usaha angkutan perairan. Dengan kata lain,

13 Soerjono Soekanto, Penegakan Hukum, Bina Cipta, Bandung, 1983, hal. 5 
peraturan atau undang-undang tentang pelayaran sudah baik dan jelas artinya mempunyai kepastian hukum yang jelas dan tidak mengandung ambiguitas atau kemungkinan mempunyai makna ganda. Selain itu peraturan-peraturan yang berada dibawah undang-undang baik itu peraturan pemerintah maupun Keputusan Menteri sudah mempunyai sinkronisasi.

Oleh karena itu, menurut Undang-Undang Pelayaran, yang merupakan dasar legal formal pengelolaan angkutan di perairan, pengelolaan KC. Kartini 1 harus dilakukan oleh badan hukum Indonesia atau warga negara Indonesia yang mendapat izin pemerintah. Selain itu, pemerintah daerah dalam mengeluarkan kebijakan tentang angkutan di perairan harus berpijak pada peraturan di atasnya, baik undang-undang, peraturan pemerintah maupun keputusan menteri

\section{KESESUAIAN PENGELOLAAN KAPAL CEPAT KARTINI 1 DENGAN UNDANG-UNDANG PELAYARAN}

Pengelolaan yang selama ini dilakukan oleh Dinas Perhubungan, Komunikasi dan Informatika Provinsi Jawa Tengah dan Dinas Perhubungan Kabupaten Jepara belum sesuai dengan beberapa Pasal yang mengatur tentang angkutan laut dalam Undang-Undang Pelayaran. Selain itu berdasarkan hasil rapat pengelolaan Kapal Cepat Kartini 1 pada Agustus 2008 yang dihadiri oleh pihak Pemerintah Daerah Jawa Tengah dan Pemerintah Kabupaten Jepara ditetapkan bahwa pengelolaan Kapal Cepat Kartini 1 yang dilaksanakan oleh Pemerintah Provinsi Jawa Tengah dan Pemerintah Kabupaten Jepara sejak tahun 2004 hingga saat ini secara legal formal tidak sesuai dengan ketentuan yang berlaku, yaitu Undang-Undang nomor 17 tahun 2008 jo Undang-Undang Nomor 21 tahun 1999 tentang pelayaran berikut peraturan pelaksanaannya yaitu Peraturan Pemerintah Nomor 82 tahun 1999 
tentang Angkutan Perairan dan Keputusan Menteri Perhubungan

Nomor KM. 33 tahun 1999 tentang Penyelenggaraan dan Penguasaan Angkutan Laut.

Hal ini tidak sesuai dengan teori Berl Kutschinky, dimana salah satu faktor dalam penegakan hukum adalah kesadaran hukum masyarakat. Menurut teori tersebut kesadaran hukum adalah variabel yang berisi 4 komponen yaitu ${ }^{14}$ :

1. Komponen Legal Awareness yaitu aspek mengenai pengetahuan terhadap peraturan hukum yang dimiliki oleh masyarakat.

2. Legal Acquaintances : pemahaman hukum. Jadi orang memahami isi daripada peraturan hukum, mengetahui substansi dari UU.

3 Legal Attitude (sikap hukum). Artinya kalau seseorang sudah memberikan apressiasi \& memberikan sikap : apakah UU baik/ tidak, manfaatnya apa.

4. Legal Behavior (perilaku hukum), orang tidak sekedar tahu, memahami tapi juga sudah mengaplikasikan.

Artinya apabila kesadaran hukum masyarakat sudah tinggi maka akan muncul kesadaran mengenai pengetahuan terhadap peraturan hukum, pemahaman hukum, sikap hukum dan perilaku hukum.

Oleh karena itu, dalam pengelolaan KC. Kartini 1, kesadaran hukum para penerap hukum masih kurang. Hal ini bisa dilihat dari pengelolaan yang belum sesuai dengan ketentuan yang ada. Ketidaksesuaian antara ketentuan dan implementasi dilapangan juga diakui oleh pihak pengelola :

"Pengelolaan kapal cepat seharusnya dikelola oleh badan usaha yang berstatus atau memiliki badan hukum tidak seperti dalam pengelolaan pada kapal Kartini......." 15

14 Anonim, Sosiologi Hukum Catatan, http://unisri.ac.id/anita/wpcontent/uploads/2008/09/sosiologi-hukumbarubgt.doc, akses tanggal 2 Nopember 2008.

15 Wawancara dengan Drs. Eka Priyambodo di kantor Dinas Perhubungan tanggal 25 November 2008. 
“.....Karena kita bukan operator kapal, kita bertindak sebagai operator sekaligus regulator, yang lain juga ada tapi masih bisa kita atasi. Itu karena kita sudah melanggar undangundang pelayaran, kita bukan badan hukum tapi mengeoperasikan kapal....."

Selain itu juga untuk melegalkan secara administrasi supaya Kapal Cepat Kartini 1 bisa beroperasi, hanya melakukan penunjukkan kepada pihak ketiga sebagai operator Kapal Cepat Kartini 1. Sedangkan, pengelolaan dilapangan atau manajemennya masih dilakukan oleh Dinas Perhubungan, padahal seharusnya pengelolaan dilakukan secara lelang kepada pihak ketiga. Hal tersebut terlihat dari hasil wawancara sebagai berikut :

“.......PT. Pualam Emas hanya sebagai bendera saja untuk melegalkan agar kapal ini dapat berjalan, karena perijinan untuk kapal laut sangat ketat itu mengisyaratkan adanya badan usaha. Kami bukan badan usaha.dalam pengelolaannya orang-orang dinas perhubunganlah yang bekerja........"17

Penyalahan aturan kebijakan yang dibuat pemerintah seharusnya tidak terjadi menurut James E. Aderson bahwa kebijakan merupakan serangkaian tindakan yang mempunyai tujuan tertentu yang diikuti dan dilaksanakan oleh seorang pelaku atau sekelompok pelaku guna memecahkan suatu masalah tertentu, namun dari teori kebijakan tersebut belum dapat dilaksanakan sepenuhnya oleh Dinas Perhubungan.

Namun demikian, kelaziman pelanggaran hukum oleh pemerintah menurut Felix A. Nugro, dikategorikan dalam 9 (sembilan) bentuk pelanggaran ${ }^{18}$ yaitu :

1. Ketidakjujuran (dishonesty)

2. Berperilaku tidak etis (unethical behavior)

Wawancara dengan Bpk. Herlan via telephone tanggal 27 Nopember 2008. Wawancara dengan Drs. Eka Priyambodo di kantor Dinas Perhubungan tanggal 25 November 2008.

18 Winahyu Erwiningsih, Makalah Peranan hukum dalam Pertanggungjawaban Perbuatan Pemerintah (Bestuurshandeling) Suatu Kajian dalam Kebijakan Pembangunan Hukum 
3. Mengesampingkan hukum (overidding the law)

4. Memperlakukan pegawai secara tidak patut (unfair treatment of employees)

5. Melanggar prosedur hukum (violations of procedural due process)

6. Tidak menjalin kerjasama yang baik dengan pihak legislatif (failure to respect legislative intent)

7. Pemborosan dalam penggunaan sumber daya (gress inefficiency)

8. Menutup-nutupi kesalahan yang dilakukan oleh aparatur (covering up mistakes)

9. Kegagalan untuk melakukan inisiatif dan terobosan yang positif (failure to show inisiative)

Dinas Perhubungan, Komunikasi dan Informatika Provinsi Jawa Tengah dan Dinas Perhubungan Kabupaten Jepara merupakan institusi pemerintah dan bukan badan hukum Indonesia yang khusus bergerak dalam bidang pelayaran sebagaimana diamanatkan dalam undang-undang pelayaran, sehingga dalam hal ini pengoperasian Kapal Cepat Kartini 1 belum sesuai dengan landasan legal formal yang benar. Dengan kata lain pengelolaan KPC Kartini 1 selama ini telah melanggar Undang - Undang Pelayaran dan peraturan-peraturan pendukung lainnya.

\section{FAKTOR-FAKTOR YANG MENJADI KENDALA DALAM PENGELOLAAN KAPAL CEPAT KARTINI 1}

Pengelolaan Kapal Cepat Kartini 1 sejauh ini masih ditemukan kendala-kendala dalam pengoperasiannya. Menurut Setyawan perencanaan dan pelaksanaan suatu pengelolaan tidak dapat terwujud hanya dalam sekali kegiatan, tetapi harus dilakukan berulang kali secara terus menerus ${ }^{19}$. Hal ini dilakukan dengan menggunakan sarana dan pendekatan apapun yang paling sesuai dengan masing-masing kondisi secara politik dan kelembagaan.

19 Setyawan. R, L. Tri, Konsep Dasar dan Masalah Pengaturan Pengelolaan Pesisir Terpadu Dalam Lingkup Nasional, Ghradika Bhakti Litiga Press, Semarang, 2005, hal. 76 
Berdasarkan hasil penelitian munculnya kendala-kendala dalam pengelolaan Kapal Cepat Kartini 1 karena faktor kelembagaan, faktor keuangan, faktor sarana/prasarana wisata dan jarak tempuh terakhir faktor profit atau keuntungan. Pertama, faktor kelembagaan merupakan kendala yang muncul sejak pengelolaan Kapal Kartini 1 diserahkan kepada Dinas Perhubungan, Komunikasi dan Informatika Provinsi Jawa Tengah dan Dinas Perhubungan Kabupaten Jepara, karena kedua institusi ini merupakan lembaga pemerintah yang berfungsi sebagai regulator. Namun demikian dalam pengetolaan Kapal Kartini 1 ini kedua institusi ini disamping sebagai regulator juga sebagai operator. Seperti yang diungkapkan oleh Kabid Angkutan Laut Dinas Perhubungan Kabupaten Jepara berikut:

"......banyak kendala tapi yang paling sulit karena kita bukan operator kapal, tapi disini kita bertindak sebagai operator sekaligus regulator, yang lain juga ada tapi masih bisa kita atasi........" 20

Pernyataan tersebut di atas mempunyai arti bahwa tidak ada garis komando yang jelas antara regulator dan operator. Kondisi ini menunjukkan bahwa pengelolaan Kapal Cepat Kartini 1 sudah melanggar ketentuan yang ada.

Kedua, faktor keuangan dalam hal ini berkaitan dengan masalah anggaran, karena sumber dana pemeliharaan, perawatan dan operasional Kapal Cepat Kartini 1 dari Anggaran Pendapatan Belanja Daerah. Kendala yang dihadapi pengelola karena adanya perbedaan dalam mekanisme pembayaran dan pelaporan. Artinya sistem akuntasi pemerintahan menghendaki setiap pengeluaran harus didasarkan pada bukti pembayaran yang valid dahulu baru kemudian uang dikeluarkan. Disamping itu, pengeluaran harus mengacu pada anggaran yang diusulkan, sehingga akan muncul

20 Wawancara dengan Bpk. Herlen via telephone tanggal 27 Nopember 2008. 
masalah apabila ada pengeluaran yang tidak termuat dalam pos anggaran. Karena pihak pengelola dalam mengoperasionalkan kapal terkadang menghadapi hal-hal yang tidak terduga dan memerlukan anggaran untuk menyelesaikannya. Apabila kegiatan tersebut tidak diusulkan dalam anggaran maka kegiatan tersebut tidak bisa dikerjakan. Kasie Angkutan Laut Dinhubkominfo mengungkapkan bahwa untuk mengelola Kapal Kartini 1 sangat memerlukan dana/anggaran karena kondisi lapangan yang tidak tentu, sedangkan pembiayaan untuk APBD sangat ketat, sehingga kegiatan Kapal Kartini terkadang batal.

Faktor ketiga yaitu faktor sarana/prasarana wisata dan jarak tempuh. Sarana/prasarana wisata di Karimunjawa yang belum ditata dengan baik menjadi salah satu kendala dalam operasional Kapal Cepat Kartini 1. Pada tahun perfama pengoperasian KPC. Kartini 1 jumlah penumpang tergolong baik, namun perkembangan dari tahun ke tahun jumlah penumpang justru menurun . Hal ini disebabkan para pengunjung merasa kecewa dengan kondisi Kepulauan Karimunjawa yang belum dikelola secara maksimal. Sektor pariwisata yang tidak ditangani pemerintah daerah dengan baik berdampak pada sektor transportasi. Menurut teori Soerjono Soekanto ${ }^{21}$, faktor sarana / fasilitas pendukung merupakan salah satu faktor yang mempengaruhi penegakan / keefektifan hukum. Oleh karena itu, ketentuan-ketentuan dalam Undang-Undang Pelayaran yang berkaitan dengan pengelolaan KC. Kartini 1 belum bisa ditegakkan karena faktor sarana / fasilitas yang belum mendukung. Artinya kendala ini akan teratasi apabila pemerintah daerah segera menata dan mengelola sektor pariwisata di Kepulauan Karimunjawa. Apabila fasilitas pariwisata di Karimunjawa ditata dengan baik maka akan meningkatkan jumlah

21 Soerjono Soekanto, Penegakan Hukum, Bina Cipta, Bandung, 1983, hal. 5 
penumpang KC. Kartini 1 sehingga pendapatan dari segi finansial nya pun akan meningkat.

Seperti yang disampaikan oleh Bapak Eka Priyambada (Kasie Angkatan Laut Dinas Perhubungan, Komunikasi dan Informatika Provinsi Jawa Tengah) :

"....hal ini disebabkan wisatawan yang berkunjung ke karimun masih terhitung sedikit karena kebanyakan yang sudah berkunjung merasa kecewa dengan kondisi pariwisata di karimun yang kurang tertata dengan baik sedangkan biayanya cukup tinggi dibandingkan dengan paket-paket wisata yang sudah ada seperti Bali atau Bunaken, disamping itu faktor jarak tempuh yang cukup jauh dan waktu jarak tempuhnya yang masih cukup lama menjadi kendala juga." 22

Faktor keempat, profit atau keuntungan. Faktor ini yang berkaitan erat dengan masalah legitimasi pengelolaan Kapal Kartini 1. Kapal Cepat Katini 1 dianggap tidak profitable sehingga tidak ada badan usaha yang tertarik untuk mengambil alih pengelolaan Kartini 1. Seperti yang disampaikan oleh Kasie Angkutan Laut Dinhubkominfo Provinsi Jawa Tengah dan Kabid Angkutan Laut Dinas Perhubungan Kabupaten Jepara, sebagai berikut:

"......tidak ada badan usaha yang mau mengelola Kapal Kartini 1, meskipun diadakan lelang kemungkinannya sangat kecil bahkan mungkin tidak ada badan usaha yang tertarik karena target yang harus dipenuhi tinggi , 23

"..........kita sudah melakukan berbagai upaya dengan berbagai cara tapi masalah tetap jalan ditempat karena tidak ada yang mau mengelola Kapal Kartini 1 menggantikan kita, karena pelayaran Kartini dianggap tidak menguntungkan dan terns merugi harusnya ada subsidi untuk pengelolaan kapal. Langkah kedepan akan dicoba untuk dilelangkan kalau memang tidak ada yang tertarik kita kembalikan ke DPR........" 24

22 Wawancara dengan Drs. Eka Priyambodo di kantor Dinas Perhubungan tanggal 25 November 2008.

23 Wawancara dengan Drs. Eka Priyambodo di kantor Dinas Perhubungan tanggal 25 November 2008.

24 Wawancara dengan Bpk. Herlan via telephone tanggal 27 Nopember 2008. 
Pengalihan pengelolaan Kapal Cepat Kartini 1 kepada pihak ketiga secara hukum perlu ditegaskan dengan bukti pengalihan ataupun bukti penugasan pengelolaan yang secara jelas menunjukkan dasar hukum yang dipergunakan serta aspek-aspek kerjasama yang dituangkan. Keberadaan bukti ini akan menjadi dasar hukum yang jelas bagi pengelolaan Kapal Cepat Kartini 1. Oleh karenanya dibutuhkan pemikiran secara rasional untuk membuat pengelolaan Kapal Cepat Kartini 1 ini menjadi lebih dapat memberikan keuntungan dan berkesinambungan dalam jangka panjang. Adapun alternatif pengelolaan Kapal Cepat Kartini 1 untuk masa mendatang meliputi : 1) Pengelolaan bersubsidi, 2) Dilelang kepada pihak ketiga, 3) dibentuk badan layanan umum daerah, serta 4) Dialihakan menjadi pengelolaan kapal perintis.

\section{PENUTUP}

\section{KESIMPULAN}

Berdasarkan basil penelitian yang telah dilakukan maka dapat diambil beberapa kesimpulan sebagai berikut;

a. Pengelolaan Kapal Cepat Kartini 1 menurut Undang-Undang No. 21 tahun 1992 tentang Pelayaran yang sudah diperbaharui dengan Undang-Undang Nomor 17 Tahun 2008 tentang pelayaran, bahwa penyelenggaraan usaha angkutan dilakukan oleh badan hukum Indonesia yang bergerak khusus di bidang usaha angkutan di perairan; usaha angkutan di perairan dapat juga diselenggarakan oleh warga negara Indonesia dengan izin pemerintah.

b. Pelaksanaan pengelolaan Kapal Cepat Kartini 1 belum sesuai dengan Undang-undang yang berlaku karena dilaksanakan oleh unsur pemerintah sendiri dan belum memenuhi ketentuan intenasional mengenai standar pelayaran intemasional berupa International Safety Maritime (ISM) Code. 
c. Kendala-kendala pengelolaan Kartini 1 muncul karena beberapa faktor yaitu faktor kelembagaan, keuangan, sarana/prasarana wisata dan jarak tempuh serta faktor profit atau keuntungan.

\section{SARAN}

Saran yang dapat diberikan dalam pengelolaan Kapal Cepat Kartini 1 adalah pengelolaan dan pengoperasian Kapal Cepat Kartini 1 diserahkan kepada pihak ketiga yaitu Badan Hukum Indonesia yang bergerak di bidang usaha angkutan di perairan (Perusahaan Pelayaran) melalui mekanisme tender atau pelelangan dengan pemberian target pendapatan, selain itu pelaksanaan pengelolaan Kapal Cepat Kartini 1 dapat juga diserahkan kepada Badan Usaha Milik Daerah (BUMD) yang bergerak di bidang usaha angkutan di perairan sebagai penyertaan modal atau dengan pola kerjasama.

\section{DAFTAR PUSTAKA}

Anonim, Sosiologi Hukum Catatan, http://unisri.ac.id/anita/wpcontent/uploads/2008/09/sosiologi-hukumbarubgt.doc, akses tanggal 2 Nopember 2008.

Basah Sjachran, Hukum Administrasi, Alumni, Bandung, 1992.

Erwiningsih Winahyu, Makalah Peranan hukum dalam Pertanggungjawaban Perbuatan Pemerintah (Bestuurshandeling) Suatu Kajian dalam Kebijakan Pembangunan Hukum.

Rahardjo, Satjipto, Masalah Penegakan hukum, Sinar Baru, bandung, 1986

Soekanto, Soerjono, Penegakan Hukum, Bina Cipta, bandung, 1983

Triyanto, Djoko, Bekerja di Kapal, Mandar Maju, Bandung, 2005.

Tri Setyawan. R, L., Konsep Dasar dan Masalah Pengaturan Pengelolaan Pesisir Terpadu Dalam Lingkup Nasional, Ghradika Bhakti Litiga Press, Semarang, 2005. 
Wignjosoebroto, Soetandyo, Masalah metodologi dalam Penelitian Hukum sehubungan dengan Masalah Keragaman Pendekatan Konseptualnya, Makalah pada Pelatihan Metodologi Penelitian, Fak. Hukum UNDIP, Mei 1999.

Warassih, Esmi, Pranata Hukum, Sebuah Telaah Sosiologis, PT. Suryandaru Utama, Semarang, 2005.

Dinas Perhubungan dan Telekomunikasi Provinsi Jawa Tengah, Studi Optimalisasi Pengoperasian KPC. Kartini 1, 2007.

Kesepakatan Bersama Gubernur Jawa Tengah dan Bupati Jepara dengan Direktur Utama PT PAL INDONESIA No. 4 Tahun 2003

No. $552.2 / 0452 / 2003$

No. 05/AAOO/II/2003

tentang Pengadaan Kapal Penumpang Cepat untuk Lintas Jepara Karimunjawa.

Keputusan Bersama Gubernur Jawa Tengah dan Bupati Jepara Nomor 55 Tahun 2004/01 Tahun 2004 tentang Kerjasama Pemerintah Provinsi Jawa Tengah dengan Pemerintah Kabupaten Jepara.

Keputusan Menteri Perhubungan No. 33 tahun 2001 tentang Penyelengaraan dan Pengusahaan Angkutan Laut.

Peraturan Daerah Provinsi Jawa Tengah No. 6 Tahun 2008 tentang Organisasi dan Tata Kerja Dinas Daerah Provinsi Jawa Tengah.

Peraturan Gubernur Jawa Tengah Nomor 523 tahun 2008 tentang Penunjukkan Kepala Dinas Perhubungan, Komunikasi dan Informatika Provinsi Jawa Tengah sebagai Pengelola Kapal Penumpang Cepat Kartini I.

Perjanjian Kerjasama Nomor 56 dan 10 Tahun 2004 tentang Pengadaan dan Pengelolaan Kapal Penumpang Cepat untuk Lintas JeparaKarimunjawa.

Peraturan Pemerintah No. 82 Tahun 1999 tentang Angkutan di Perairan.

Undang-Undang No. 21 Tahun 1992 Tentang Pelayaran.

Undang-Undang No. 17 Tahun 2008 Tentang Pelayaran. 
